deficits usually double between one April and the next. This time the government must hope that economic freedom will abate this tendency. If not, there will be inflation, the poor will feel even more poor and the momentum of development will be interrupted. Even the government acknowledges that it is betting on a favourable monsoon. We should all keep our fingers crossed.

Mr Nigel Lawson will quickly plead that a British finance minister could not dream of taking such risks; for one thing, what with the developed luxury of a welfare system, his government's spending is a much larger proportion of the national wealth. Yet Mr Lawson's problem for the past year has been very much like Mr V.P. Singh's: how to create a climate in which such wealth as there may be is directed towards productive investment, preferably in innovation. The pre-budget calculation seems to have been that a replacement of direct by indirect taxation would give saving an edge, and that it would be beneficial if the favourite media for personal savings (mortgages and pensions) could be put on an equal footing with investments in risky ventures. In the event, the British government found it lacked the courage to give such offence to its electors. Nor could it go along with the entreaties of its political opponents (not to mention a substantial section of its own political party) that the annual deficit should be deliberately increased so as to stimulate demand. (Relatively credit-worthy Britain's deficit will nevertheless be twice India's.) So Mr Lawson emerges as a piteous character, "boxed in" as he describes himself. No doubt he will be laughing if India comes a cropper, perhaps because the monsoon fails in June. But will he not be furious with himself, perhaps even as furious as his taxpayers will be with him, if India's gamble comes off when he can boast only that he did not think it the right time to make a risky budget?

\section{New star wars row}

\section{The private dispute at Geneva over star wars may} yet be drowned by rows between allies.

MR Richard Perle, Assistant Secretary of Defense at the Pentagon, is one of the US administration's hard men, and was probably hired for that attribute, not for his skill as a diplomatist. But even so, his performance in London last week inevitably raises the question whether his operating licence should be amended.

The circumstances are very odd. Two weeks ago, Sir Geoffrey Howe, the British Foreign Secretary, had made a speech in which he made quite clear his support for research under the umbrella of the Strategic Defense Initiative and then went on to muse about the problems that would arise if ever the time came to deploy an effective defence against ballistic missiles. There would have to be negotiations with the Soviet Union about the scale and manner in which this would be done. And even when agreement had been reached, there would remain difficulties about the true measure of security an apparently leak-tight umbrella could provide, if only because the present familiarity of strategic doctrines, bizarre though they may seem, would be undermined. Sir Geoffrey went on to reflect that the difficulties he foresaw might never arise because the research programme might demonstrate that the goal is unattainable. None of this conflicts with what is understood to be the objective of the research now under way, at least since the British prime minister's pre-Christmas visit to Washington last December.

So why should Mr Perle promptly launch an attack on Sir Geoffrey at a conference held in Britain just a few days afterwards? The most charitable explanation is that he read only a bowdlerized version of Sir Geoffrey's speech, or that he was himself misquoted, or quoted out of context. Yet another explanation, so mundane that it must seem an insult to such a person as Mr Perle, is that he was jet-lagged. Yet people in his trade do not usually set about supposedly friendly statesmen with such vigour, and in public, so that some kind of explanation is essential. Otherwise, as Mr Perle must by now recognize, there is a danger that listeners will think there must be more to star wars, even now, than mere research.

\section{Illegality proliferates}

The US administration should be more diligent

\section{in preventing nuclear proliferation}

FOR an administration that has been concerned - some would say obsessed - with halting the flow of US technology to the East, the Reagan Administration has been curiously apathetic about nuclear non-proliferation. So it comes as no surprise that its apathy should set the tone for the government's law-enforcement officials responsible for federal statutes designed to prevent sensitive nuclear-weapons technology from reaching nonweapons states. There is no other explanation for the strange case of a Pakistan national arrested last year when he attempted to ship home 50 high-speed switches that just happen to be of a kind needed for building an atomic bomb. Nazir Ahmed Vaid was allowed to plead guilty to one count of violating US export laws; he received a suspended sentence and was quickly deported. Although the original indictment had made clear that the switches were sensitive nuclear technology and suggested that Vaid was working on behalf of the Pakistan government, all such references were dropped in the plea bargain. The judge who approved the plea bargain said there was no evidence that Vaid was a foreign agent; he was merely a businessman "expediting what he thought was a business deal". The federal prosecutors agreed.

An investigation by the New York Times has now uncovered a very different story. In fact, the government had in its hands proof that Vaid was acting directly as an agent for one S.A. Butt, who happens to be the director of supply and procurement for the Pakistan Atomic Energy Commission. Telexes from Vaid to Butt make it clear that Vaid knew it was illegal to export the switches without a licence, that he was working on "alternate ways to buy these products" after a direct approach to the sole manufacturer failed and asking what he should say the "ultimate consumer" of the products was. Butt cabled back that he should say the ultimate consumer was the research and development department of Islamabad University. The prosecutors told the Times reporter that they had not appreciated the significance of these telexes because they had not been able to find out who Butt was. (He had no record in the US Department of Treasury crime computer, they said.) Butt is in fact well known in arms control circles as the man who successfully procured reprocessing and enrichment technology for Pakistan from Europe in the 1970s. Had these facts come out at a trial, Vaid could have been sentenced to as much as $\mathbf{2 0}$ years' imprisonment for violating the Atomic Energy Act.

Precisely what Pakistan is about is anybody's guess. Since the Indian explosion in May 1974, Pakistan has encouraged speculation that it is on the way to making some kind of bomb. Most probably it has been doing its best, with help from where it could be had, people like Vaid included. On present form, dependent as it is on the United States for delivery systems, Pakistan could not realistically hope to be an independent nuclear power, but it could reasonably hope to be able to make trouble. For the past five years, the United States has been ambivalent, reckoning Pakistan an ally on Afghanistan. Until recently and perhaps still, it has fudged the nuclear issue.

It is not necessary to subscribe to conspiracy theories to see a connection between the administration's laxity on nuclear nonproliferation and the laxity of a federal prosecutor in Houston in pursuing this case vigorously. Prosecutors have a limited amount of time to devote to too many cases; they are not going to knock themselves out on cases that will not win them approval at a higher level. The administration has unmistakenly set the tone, a blend of laxity and of contempt for the law, or at least for the spirit of President Carter's Nuclear Non-Proliferation Act. The act may rashly have offended governments which believed that their obligations under the Non-Proliferation Treaty (NPT) were sufficient and may unwisely have overridden legal contracts, but is there any reason why it should not apply to countries which have scorned the NPT and which have no other claims on the United States? 